\title{
CEO Narcissism and the Takeover Process: From Private Initiation to Deal Completion
}

\author{
Nihat Aktas $^{1,2}$, Eric de Bodt ${ }^{2,1}$, Helen Bollaert ${ }^{1,2}$, and Richard Roll ${ }^{3}$ \\ ${ }^{1}$ SKEMA Business School, Avenue Willy Brandt, F-59777 Euralille, France \\ ${ }^{2}$ Univ. Lille Nord de France, 1 place Déliot - BP381, F-59020 Lille, France \\ ${ }^{3}$ UCLA Anderson, 110 Westwood Plaza, Los Angeles, CA 90095-1481, USA
}

This draft: December 05, 2011

\begin{abstract}
CEO narcissism affects the M\&A process. More narcissistic target CEOs obtain higher bid premiums. Acquirer shareholders react less favorably to a takeover announcement when the target CEO is more narcissistic. Among acquiring CEOs, narcissism is associated with initiating deals and negotiating faster. Higher narcissism in both target and acquirer CEOs is associated with a lower probability of deal completion. Interactions between acquirer and target CEO narcissism play a significant role. To obtain these results, narcissism is measured by the prevalence of personal pronoun usage in more than 1,700 transcripts of CEO speech.
\end{abstract}

JEL classification: G34

Keywords: mergers and acquisitions; takeover process; CEO; narcissism; hubris; overconfidence

\section{Acknowledgments}

We thank Audra Boone, François Derrien, Jarrad Harford, Sebastien Michenaud, Christophe Pérignon, Luc Renneboog, Armin Schwienbacher, Geoffrey Tate, Karin Thorburn, and participants of the European Finance Association annual meeting 2011 (Stockholm) for their comments and suggestions.

E-mail addresses: nihat.aktas@skema.edu (N. Aktas), eric.debodt@univ-lille2.fr (E. de Bodt), helen.bollaert@skema.edu (H. Bollaert), rroll@anderson.ucla.edu (Richard Roll). 
Individual CEO psychology seems to influence the propensity to acquire and the market's reaction to takeover announcements (see, e.g., Hayward and Hambrick (1997), Chatterjee and Hambrick (2007), Malmendier and Tate (2008), John, Liu, and Taffler (2011)). But the impact of psychology on all aspects of the takeover process is still unfinished business. Most previous research focuses on the acquirer CEO (with the notable exception of John, Liu, and Taffler (2011)), but takeovers involve bargaining, so the personalities of the two main protagonists, the acquirer and target CEOs, are likely to be of paramount importance. We supplement existing research by studying the effects of CEO psychology on both sides during the entire takeover process, from the private phase that begins with deal initiation right through to deal completion.

We focus on the psychological trait of narcissism. There are some similarities among narcissism, hubris and overconfidence, but the former has distinctive features that promise to make it highly relevant for M\&A. First, narcissistic individuals must continuously undertake actions that reinforce their self-image and maintain their ideal ego (Buss and Chiodo (1991), Chatterjee and Hambrick (2007)). Thus, one would expect this need to manifest itself fully when large stakes are involved, such as around takeover attempts. Second, narcissists are manipulative and lack empathy (American Psychiatric Association (1994)), characteristics that seem likely to influence merger negotiations. Third, narcissism is a well-defined concept grounded in psychology theory for which researchers have developed seemingly sound indirect measures. Finally, the literature in strategic management makes a convincing case for the importance of CEO narcissism in a variety of firm activities and outcomes (Kets de Vries and Miller (1985), Chatterjee and Hambrick (2007)).

The study of CEO psychology in the M\&A context is rooted in the hubris hypothesis (Roll (1986)), which nominates CEO hubris as an explanation of puzzling losses for acquiring shareholders upon the announcement of an acquisition. Hubris causes CEOs to bid too high for a target because they overestimate the value of potential synergies. Empirical researchers have sought to test the hubris 
hypothesis by establishing a link between acquirer CEO hubris, bid premiums and market reactions. Hayward and Hambrick (1997) show that acquirer CEO hubris is positively related to the bid premium and negatively related to subsequent acquirer performance. Malmendier and Tate (2008) find that overconfident CEOs are more likely to carry out acquisitions but that markets react less favorably to acquisition announcements made by such overconfident CEOs. John, Liu, and Taffler (2011) find that overconfident CEOs pay higher bid premiums and that this effect is reinforced when the target CEO is also overconfident. Similar findings are reported by Chatterjee and Hambrick (2007), who show that narcissistic CEOs in the computer industry carry out more and larger acquisitions.

There is every reason to expect that CEO psychology affects more than their propensity to acquire and the value effects of acquisition. There is ample evidence in the literature that executive psychology sets the tone at the top of the firm and matters for a variety of firm decisions and strategies. Kets de Vries and Miller (1985), relying on an individual clinical approach, show that narcissistic top managers are more likely to undertake actions that are personally beneficial to them, even if these might damage the interests of the organization. Studies based on large samples of firms provide additional evidence for the importance of CEO psychology. The investment decisions of firms run by overconfident CEOs are more sensitive to cash flow (Malmendier and Tate (2005)). The capital structure of the firm is affected by the overconfidence of top executives (Malmendier, Tate, and Yan (2011)). Li and Tang (2010) find, in a sample of Chinese firms, that hubristic CEOs have a greater propensity to take risks. Chatterjee and Hambrick (2007) show that the operating and market performance of firms led by narcissistic CEOs is more extreme and more volatile than that of firms run by less narcissistic CEOs. Goel and Thakor (2010) show that CEO envy may even explain M\&A waves. Given that the psychological propensities of CEOs are felt over a wide range of firm decisions, activities and outcomes, we can expect them to be much in evidence throughout the different steps of the takeover process. 
Building on the theoretical analysis provided by Hansen (2001), Boone and Mulherin (2009) propose a practical framework for studying the takeover process. They separate the process into eleven steps, starting from the initiation to the completion of the deal. Seven of the eleven steps take place before the deal is made public. To study this large private portion of the takeover process, researchers, following Boone and Mulherin (2007), consult the merger background section of relevant Securities and Exchange Commission (SEC) filings, a rich source of private information (see, e.g., Aktas, de Bodt, and Roll (2010), Fich, Cai, and Tran (2011), Guo, Hotchkiss, and Song (2011)).

Our study starts by assessing how CEO narcissism affects the bid premium and acquirer announcement returns. The existing literature provides results on the relation between hubris and bid premiums (Hayward and Hambrick (1997)), and between overconfidence and acquirer cumulative abnormal returns (Malmendier and Tate (2008)). In addition, John, Liu and Taffler (2011) show that overbidding by overconfident CEOs is reinforced when the target CEO is also overconfident. The literature remains however silent on whether the same effects are observed in the case of CEO narcissism. As the two psychological concepts present some marked differences, it would be hazardous to speculate on whether the effects should be identical.

Our next step is to analyze the impact of CEO narcissism on deal initiation. Few studies have been carried out thus far on the determinants of deal initiation, a notable exception being Simsir (2009). Although the author does not include variables representing CEO psychology, his work does uncover some control variables that influence whether the acquirer or the target is the initiating party, such as leverage and firm size. While overconfident CEOs tend to make more acquisitions than their nonoverconfident counterparts (Malmendier and Tate (2008)), we have no information about whether such acquirers tend on average to participate in sale processes initiated by the target, or whether these acquirers are on average the initiator of the takeover process. 
We next turn our attention to the effect of CEO narcissism on the length of the private part of the takeover process (from the very beginning to the public announcement). Jemison and Sitkin (1986) is one of the rare papers to deal specifically with the length of the takeover process. ${ }^{1}$ The authors develop a complete theoretical model of the acquisition process. The first part of the model describes factors that affect the speed from deal beginning to announcement and, as far as we are aware, has never been tested empirically. The model posits that, among other factors, higher levels of acquiring CEO overconfidence will cause the deal to be made more quickly.

We consider finally whether CEO narcissism affects the likelihood of the deal being effectively completed. Around 10\% of domestic deals announced by listed U.S. acquirers between 1990 and 1999 were cancelled (see, e.g., Bates and Lemmon (2003), Luo (2005)). There are various reasons for deal cancellation. Target shareholders may not approve the takeover. A vote of acquiring shareholders may be required. Regulatory (antitrust) authorities may intervene, either blocking the deal entirely or approving it only on a modified basis. But little is known about the influence of CEOs' personality traits. Our paper addresses this issue by examining the impact of both target and acquirer CEO narcissism on the probability of deal completion.

We measure narcissism by tabulating personal pronoun usage. The prevalence of first person singular pronouns in speech is correlated with narcissism scores from tried and tested direct measures (Raskin and Shaw (1988)). A narcissism score for each of our sample CEOs is the ratio of first person singular pronouns to total first person pronouns in speech recorded in transcripts from 1,780 interviews. Narcissism scores for both acquiring and target CEOs are available for a sample of 146 M\&A deals over the period 2002 to 2006. The mean narcissism score for acquirer (target) CEOs is 0.215 (0.185). The difference is statistically significant and shows that, on average, acquirer CEOs in our sample tend to be more narcissistic than target CEOs.

\footnotetext{
${ }^{1}$ Another exception is Coff (1999), who examines the determinants of the negotiation time for acquisitions made by firms in knowledge intensive industries. However, Coff ignores the private part of the takeover process.
} 
We find that higher levels of target CEO narcissism are associated with higher bid premiums and less favorable market reactions by acquiring firm shareholders on announcement. These effects are economically significant. For example, a $10 \%$ increase in target CEO narcissism is associated with an increase of $6.3 \%$ in the bid premium and a decrease of $1.3 \%$ in acquirer announcement cumulative abnormal returns. Also, more narcissism in an acquirer CEO is associated with a higher probability of initiating a takeover and with a shorter private takeover process length. The narcissism of both acquirer and target CEOs reduces the likelihood of deal completion. The results reveal the importance of accounting for interactions between acquirer and target CEO narcissism. The findings are robust to alternative specifications of the narcissism measure and also to additional tests taking into account the potential simultaneity between deal initiation and choice of selling procedure (auction versus negotiation).

Our paper adds to the existing literature on managerial biases in behavioral finance. It is most closely related to studies of the effects of CEO overconfidence in the M\&A setting (Malmendier and Tate (2008), John, Liu, and Taffler (2011)), but examines a different psychological characteristic (narcissism), highlights importance of interactions between parties, and studies aspects of the takeover process beyond bidding behavior and value effects. More broadly, our work supplements studies in corporate finance that demonstrate the impact of CEO characteristics on capital investment (Malmendier and Tate (2005)), financing choices (Malmendier, Tate, Yan (2011)), and firm innovation (Hirshleifer, Low, and Teoh (2010)).

The rest of this paper is organized as follows. Section I provides a definition of narcissism, explains how it differs from other related concepts and establishes its relevance to the mergers and acquisitions setting. Section II describes the sample, data and methods used. Section III gives the results of our analyses and discusses our findings. Section IV describes the robustness checks carried out. Section V concludes. 


\section{Narcissism and Related Concepts}

Narcissism is a complex multidimensional concept whose ancestry can be traced back to Freud (1914). The DSM IV (Diagnostic and Statistical Manual of Mental Disorders, American Psychiatric Association (1994)) provides a description of narcissistic personality disorder along with a list of diagnostic criteria for use by clinicians (see Appendix A). According to the DSM IV, narcissistic personality disorder is "a pervasive pattern of grandiosity (in fantasy or behavior), need for admiration, and lack of empathy, beginning by early adulthood and present in a variety of contexts" (p. 717). The diagnostic criteria describe individuals who are characterized by an exaggerated sense of their own importance which causes them to overestimate their abilities and achievements. They require excessive admiration from others and tend to undertake grandiose and highly visible actions in order to continuously reinforce their egos. They have a grossly overdeveloped sense of entitlement and display arrogance or contempt towards others. In addition, they are interpersonally exploitative and use others to reinforce their own self-image, without experiencing the feelings of guilt that dissuade non-narcissists (Campbell and Foster (2007)).

Narcissism is related to both overconfidence and hubris, which have already been studied in the M\&A context. Overconfidence characterizes an individual's tendency to overestimate actual or relative ability and performance, or to display excessive certainty about his or her beliefs (Moore and Healy (2008)). Overconfidence is related to narcissism in that some of the arrogant attitudes evident in narcissism may be said to overlap with it. However, narcissism and overconfidence are different in one important respect. As a cognitive bias, overconfidence relates only to the perception of reality. Narcissism, on the other hand, is a complete personality trait which describes both cognition and behavior: "Narcissism is a quality of the self that has significant implications for thinking, feeling and behaving" (Campbell and Foster (2007), p. 12). The presence of both cognitive and behavioral dimensions in narcissism has two important implications. First, it brings an urgent compulsion for 
continuous reinforcement of the ideal ego, which causes an individual to act repeatedly in ways that reinforce his or her self-image (Buss and Chiodo (1991)). Second, narcissistic individuals are interpersonally exploitative and lacking in empathy (American Psychiatric Association (1994), Campbell and Foster (2007)).

A partial overlap between narcissism and hubris is highlighted by Owen and Davidson (2009). Their research is the first attempt to provide a clinical definition of hubris syndrome. ${ }^{2}$ The proposed definition takes the form of a 14-item list of attitudes and behaviors that characterize individuals with hubris. According to the authors, hubris syndrome sometimes develops when an individual accedes to a position of power and thus is found in political and business leaders. The syndrome displays some overlap with narcissistic personality disorder, as seven out of its fourteen symptoms correspond to items present in the Diagnostic Criteria for Narcissistic Personality Disorder that are listed in the DSM IV (American Psychiatric Association (1994)). The overlapping items are shown in italics in Appendix A. The other seven items are either linked to other personality disorders or are unique to hubris syndrome, and it is these that distinguish hubris from narcissism.

To sum-up, narcissism is a compelling concept to study with takeovers for four main reasons. First, there is broad consensus about the definition of narcissism and it is grounded in psychology theory. Second, it is a complex multi-faceted concept that captures cognitive and behavioral dimensions. The behavioral dimensions include both a motivational aspect and an interpersonal aspect. The former defines narcissists' continuous need for admiration and reinforcement, and the latter characterizes the manipulative nature of narcissists and their lack of empathy (American Psychiatric Association (1994), Campbell and Foster (2007)). Third, a measure of individual narcissism in large samples of individuals has been validated by research in psychology (Raskin and Shaw (1988)). Finally, previous research using both case study approaches (Kets de Vries and Miller (1985)) and the analysis of large samples (Chatterjee and

\footnotetext{
${ }^{2}$ Prior research on hubris in the M\&A setting, such as Roll (1986), does not claim to provide a clinical definition of hubris.
} 
Hambrick (2007)) provides evidence that CEO narcissism is important in explaining certain organizational activities and outcomes.

\section{Data and Methods}

\section{A. Sample}

Our sample of acquisitions covers completed deals announced over the period 2002 to 2006 and is extracted from the Securities Data Company's (SDC) U.S. Mergers and Acquisitions Database. We limit the sample to deals in which the acquirer increases its shareholdings in the target from less than $50 \%$ to 100\%. Following Masulis, Wang, and Xie (2007), we only keep significant deals (deal value provided by SDC greater than $\$ 1$ million and at least $1 \%$ of the acquirer's market value). Because we require data that is only available for listed firms, unlisted targets and acquirers are removed, cutting the sample size to 642. After collecting the required control variables for targets or the acquirers and information on the private part of the takeover process in Securities and Exchange Commission filings ${ }^{3}$ we are left with 187 deals. The use of the SEC filings also enables us to cross-check the information provided by SDC. The narcissism variable is constructed using examples of CEO speech from fair disclosure wires. We find sufficient material to estimate the narcissism score of both the target and acquirer CEO for 146 deals.

\section{B. Variables}

This subsection describes all of the variables. More complete definitions are given in Appendix B.

\section{B.1. Narcissism Indicator}

A study carried out by Raskin and Shaw (1988) shows that the proportion of first person singular pronouns to first person plural pronouns used in speech is correlated with narcissistic personality inventory (NPI) scores. ${ }^{4}$ The authors document the robustness of this finding to various factors. First, the

\footnotetext{
${ }^{3}$ We rely on SEC filings 14A and S-4 filings for mergers, and 14D filings for tender offers.

${ }^{4}$ The NPI is a questionnaire, originally based on the diagnostic criteria for narcissistic personality disorder, that provides a narcissism score for individuals and enables the measurement of narcissism in large samples rather than
} 
correlation between first person pronoun usage and NPI scores is robust to age, gender and the content of the speech analyzed. Second, the correlation persists even after controlling for other personality traits (extraversion, neuroticism, psychoticism and locus of control). Finally, the correlation between NPI scores and personal pronoun usage is only found in first person pronoun usage, and is not found in second- or third-person pronoun usage. This narcissism measure has previously been studied in strategic management by Chatterjee and Hambrick (2007).

The narcissism indicator is estimated using the proportion of first person singular (I, me, my etc) to total first person pronouns ( $I, m e, m y$, we, us, our etc) in CEO speech. This indicator enables us to capture the richness of the narcissism concept using a measure which can be estimated from publicly available information. An additional advantage of the first person pronoun narcissism indicator is that it enables us to estimate the level of narcissism for both acquirer and target CEOs. Most acquiring CEOs are readily identifiable using the Execucomp database. However, most target CEOs are not included in Execucomp and must be identified by hand using the SEC filings pertaining to the transaction. Samples of CEO speech are derived from interviews with analysts or journalists recorded on the Lexis Nexis Academic and The Wall Street Transcript databases, following Chatterjee and Hambrick (2007). We find transcripts for the year prior to the beginning of the deal process, the year the deal process began and then for all years until deal completion. This involves a manual search of the relevant databases using the CEO's name for the years in question. Although Raskin and Shaw (1988) show that the narcissism indicator does not depend on the subject matter, as a precaution we avoid interviews whose subject is a merger or an acquisition, to limit the possible influence of the deal itself on the narcissism measure. We also do not use interviews about litigation because of the specific nature of the language used. We further exclude transcripts of annual general meetings, which might be scripted, and any analyst

on a case-by-case basis (for examples of studies validating the NPI, see, e.g., Emmons (1987), Raskin and Hall (1979), Raskin and Hall (1981)). It measures narcissism along four dimensions: exploitativeness/entitlement, leadership/authority, superiority/arrogance and self-absorption/self-admiration. 
interview where the CEO simply makes a presentation and does not respond spontaneously to analyst questions.

The search for transcripts of CEO interviews yields 1,780 documents for 334 CEOs. The vast majority of the transcripts are from conference calls with analysts, which can be either quarterly earnings calls or industry-specific calls. Typically, the conference involves at least three participants from the firm, and sometimes more. In addition to the CEO, the CFO and the Head of Investor Relations are also present, with other executive officers in some cases. We manually expunge the speech of everyone except the CEO (an example of clean CEO speech is provided in Appendix C). Then, with a specially created computer program, we count the number of utterances of first person singular and first person plural pronouns for each CEO. ${ }^{5}$ The variable CEO narcissism is equal to the ratio of first person singular pronouns to all first person pronouns over all available interviews A continuous measure of narcissism is consistent with the prevailing view in psychology, which disputes the dichotomous nature of the concept and emphasizes that it is continuous (Campbell and Foster (2007)). Continuity in narcissism is important for this study. Since CEOs are successful people, it would be hard to imagine that their narcissism ever rises to a dysfunctional level. Continuity implies that even a low level can be relevant.

Descriptive statistics for narcissism are provided in Panel A of Table I. The mean narcissism score for acquiring CEOs is 0.215 , which is around 0.03 higher than that of target CEOs. The score for acquiring CEOs is consistent with existing literature, as Chatterjee and Hambrick (2007) find a mean first person pronoun-based narcissism score among the CEOs in their sample (of whom many head acquiring firms) of 0.21 . The difference in means between acquirer and target CEOs is significant at the $1 \%$ level (unreported), indicating that the acquiring CEOs are, on average, more narcissistic than the target CEOs in our sample. Sample CEOs display considerable variation in narcissism; the minimum score for both acquirer and target CEOs is less than 0.1 and the maximum score is in excess of 0.4 in both cases.

\footnotetext{
${ }^{5}$ First person singular pronouns are $\mathrm{l}, \mathrm{me}, \mathrm{my}$, mine and myself. First person plural pronouns are we, us, our, ours and ourselves.
} 
(Insert Table I about here)

In addition to the narcissism of each CEO separately, we examine their interaction by multiplying acquirer CEO narcissism by target CEO narcissism.

\section{B.2. Dependent Variables}

The bid premium is the share price offered by the winning bidder deflated by target's price four weeks prior to the announcement date. To assess market reactions to the takeover announcement, we use the acquirer's cumulative abnormal returns (CARs), computed as in Fuller, Netter, and Stegemoller (2002) and Moeller, Schlingemann, and Stulz (2005), with the Beta-one model; this subtracts the daily market portfolio return ${ }^{6}$ from the daily company return. We use an 11-day event window centered on the announcement date.

The initiating party is readily identifiable in the text of the SEC filing. In the case of target initiation, the board may direct the CEO or an external advisor to seek opportunities to combine with or be acquired by another firm. In the case of acquirer initiation, the board may decide to pursue a strategy of external growth. We exclude deals where the identity of the initiating party is impossible to determine. The acquirer initiated dummy is 1.0 when true, or zero otherwise.

The private takeover process length is the difference (in months) between the date when the process began and the announcement date. The former is the date when one of the parties involved made the decision to initiate the deal; it can be found in the merger background section of the SEC filings. ${ }^{7}$ The latter is provided by the SDC database (corrected if necessary by reference to the SEC filings).

To test the probability of deal completion, ideally we would identify all deals announced by the acquirers in our sample over the period 2002 to 2006, estimate the narcissism score for all target and

\footnotetext{
${ }^{6}$ For the market return we use the CRSP value-weighted market index.

${ }^{7}$ If the beginning of a takeover process is described in the merger background section of the SEC filings, but nothing happens over the following 12 months, we qualify the beginning of the next process as a new takeover process.
} 
acquirer CEOs in both completed and uncompleted deals and then compute the effect of CEO narcissism on completion. Unfortunately, this procedure is impossible because our sample includes only completed deals. Moreover, finding CEO narcissism data for uncompleted deals is even more challenging than for completed ones and since only around $10 \%$ of announced deals are not completed (see, e.g., Bates and Lemmon (2003), Luo (2005)), the resulting sample would likely be so small as to be almost meaningless.

We therefore use investor perceptions to estimate an ex-ante measure of the probability of deal completion. Investor perceptions not only reflect reactions to the bid premium, but also include anticipations of the likelihood of deal completion (Bhagat et al. (2005)). The ratio of target cumulative abnormal returns to bid premium is used as a proxy for this ex-ante anticipation of the probability of deal completion. The proxy is however biased. Investor perceptions also include anticipations of a potential bid revision either due to pressure from target shareholders or from rival bidders. But in practice, the probability of a bid revision is likely low because there is little ex-post observed competition. Betton, Eckbo, and Thorburn (2008) report that $94 \%$ of contests to acquire a target are single bid contests in a sample of 35,727 U.S. transactions between 1980 and 2005. We therefore expect that omitting to take into account the probability of a bid revision generates a bias of second order importance. Our ex-ante probability of deal completion variable is obtained by dividing the target cumulative abnormal returns in the window $[-5,+5]$ by the one-week bid premium, excluding from our analyses those deals in which either the target cumulative abnormal returns or the bid premium are negative. ${ }^{8}$

The summary statistics presented in Panel B of Table I show that the mean bid premium is $36.14 \%$, which is slightly lower than in other research which consistently reports bid premiums of around $40 \%$ (see, e.g., Betton, Eckbo, and Thorburn (2008)). Average acquirer CAR is $-1.67 \%$, which is consistent with the findings of Moeller, Schlingemann, and Stulz (2005). Those authors find that value destruction is

\footnotetext{
${ }^{8}$ We use the one-week time interval here to estimate both the numerator (target CAR) and the denominator (bid premium) of the ex-ante probability of deal completion ratio, starting from the same point in time. The use of the four-week premium would contaminate our measure because of the presence of target run-ups.
} 
more prevalent in the acquisition of public targets and in larger firms. Our sample contains only public targets and acquirers are typically large firms, implying that negative acquirer CARs are to be expected. In our sample, $60.27 \%$ of deals are initiated by the acquirer, which is consistent with both Simsir (2009) and Aktas, de Bodt, and Roll (2010), who find that around $60 \%$ of deals are initiated by acquirers between the mid-1990s and 2007. Finally, the mean ex-ante probability of deal completion is $77.27 \%$.

\section{B.3. Control Variables}

Summary statistics for control variables are presented in Panel C of Table I. Cash dummy indicates that $40.10 \%$ of the deals in our sample are all-cash deals, which is consistent with Boone and Mulherin (2007) whose sample contains $37 \%$ of all cash deals. Using the Fama-French 49 industry classification scheme, the dummy variable horizontal deal identifies whether the acquirer and the target are both from the same industry. $64.08 \%$ of the transactions are classified as horizontal deals. To assess whether the private negotiations take place within an active M\&A market, we use the liquidity index, which is designed to capture the intensity of M\&A activity in a particular sector. Following Schlingemann, Stulz, and Walkling (2002), this variable is the value of corporate control transactions in a particular year relative to the total book value of assets of firms in the same two-digit SIC code during the same year. We include a dummy variable representing the selling procedure (auction v. negotiation) in some specifications. Following Boone and Mulherin (2007), a deal is classified as a negotiation if, according to SEC filings, the target only enters into discussions with a single potential acquirer. It is classified as an auction if several potential acquirers are mentioned. The proportion of auctions in our sample is similar to that of Boone and Mulherin (2007), who report 50.5\% of auctions for the period 1989 to 1999 while we find $50.68 \%$.

Finally, SEC filings identify multiple-bid transactions. Not all auctions terminate in formal bids by potential acquirers; in some cases, only one bidder puts in a bid. While nearly half of our sample deals are auctions, more than one potential acquirer puts in a formal bid in only $34 \%$ of cases. 
We control also for acquiring firm characteristics. Summary statistics are provided in Panel C of Table I. Governance quality of the acquirer is measured by the GIM index (Gompers, Ishii, and Metrick (2003)). The mean governance score of acquirers in our sample is 9.47, which is close to that in Masulis, Wang, and Xie (2007) who report a mean score of 9.45. The mean size (market value of equity) of the acquiring firms in our sample is $\$ 16.6$ billion, which is somewhat larger than, for example, Boone and Mulherin (2007) who report a mean acquirer size of $\$ 10.58$ billion. The mean leverage ratio of the acquiring firms in our sample is $21 \%$. Panel C of Table I indicates that $25.17 \%$ of our sample acquirers operate in a regulated industry. To assess the acquirer's M\&A experience, we provide also the number of deals carried out over the previous twenty-four months. The mean number of acquisitions is 0.39 , with values ranging from 0 to 5 .

Summary statistics for control variables relating to target firms are also provided in Panel C of Table I. The mean size of target firms is $\$ 2.90$ billion, which is similar to that reported in Boone and Mulherin (2007), $\$ 2.69$ billion. Target runup is defined as in Betton, Eckbo, and Thorburn (2009) as the target average abnormal return over the period $[-42,-6]$ days prior to the announcement date. A dummy variable identifies target firms that are listed on the NYSE/AMEX, to control for the possibility that they may differ from firms listed on the Nasdaq. The former represent thirty-one percent of our targets. The concentration of target sales is a proxy for the complexity of the target's operations. It is estimated as the Herfindahl-Hirschman concentration index of the firm's sales by business segment. Information on industry segments from Compustat are used for this calculation.

\section{Econometric Methods}

Our econometric approach depends on the nature of the dependent variable. For the bid premium, acquirer cumulative abnormal returns and ex-ante probability of deal completion regressions, we use standard ordinary least squares. For the bid premium and acquirer cumulative abnormal returns 
regressions, we include control variables from Betton, Eckbo, and Thorburn (2009). ${ }^{9}$ We use identical variable definitions to theirs, with the exception of poison pill, a proxy for governance quality, which we represent using the GIM index, and multiple bidders which we define with reference to the description of the private takeover process in the merger background section of the relevant SEC filings, rather than relying on the number of public bidders reported in the SDC database. We control for target size, method of payment and horizontal deals in the deal completion analysis.

The deal initiation variable is binary so we use a probit estimated by log-likelihood function maximization. We follow the exploratory research of Simsir (2009) to specify the appropriate control variables for the deal initiation regression. These include acquirer characteristics (leverage, size and regulated industry), target characteristics (size) and the intensity of M\&A activity in a particular sector (liquidity index).

Private takeover process length, the number of months between the beginning of the takeover process and the announcement date, suggests a count data model estimator. Initial estimations using a Poisson estimator show that the takeover process length variable displays over-dispersion in our sample. ${ }^{10}$ As a consequence we opt for the negative binomial model (the Negbin 2 model, see Greene (2008, p. 912)). Estimates are obtained by log-likelihood maximization. The control variables are from Jeminson and Sitkin's (1986) model. ${ }^{11}$ We proxy for decision making under conditions of uncertainty using the variable concentration of target sales, which captures the business segment based complexity of the target. According to Jeminson and Sitkin (1986), the more complex the deal, the more difficult the valuation process and the more the decision process takes place in a situation of uncertainty. We represent participant commitment by the target initiated dummy and board approval by the GIM index

\footnotetext{
${ }^{9}$ We exclude certain control variables because there are fewer than 5 observations for which the variable is different to zero (penny stock (target), toehold size and hostile deal).

${ }^{10}$ The expected takeover process length is significantly not equal to the variance of the takeover process length. This implies that the Poisson estimator is misspecified.

${ }^{11}$ We exclude certain factors in the original model from our analysis, such as perceived need for secrecy and the isolation of the decision-making team, because of the impossibility of capturing them using a reliable indicator.
} 
variable (more entrenched CEOs are less subject to board supervision). We include a regulatory obstacle variable in the form of acquirer in regulatory industry and control for prior acquisition experience with acquirer M\&A experience. Finally, we proxy for the financial capabilities of the acquiring company using its leverage.

We report $p$-values obtained using a percentile $t$ bootstrap (see Horowitz (2001)). The procedure is as follows: from the original data matrix, draw, with replacement, one thousand bootstrap samples with the same number of observations as in the original sample. For each of the bootstrap samples, estimate the corresponding multivariate model. This provides bootstrap coefficient estimates and corresponding bootstrap $t$-statistics. Finally, tabulate the empirical distribution of the bootstrap $t$ statistics coefficient under the null hypothesis of no effect for each coefficient and use this distribution to test the significance of the regression coefficients. We use case-by-case resampling to ensure that our results are robust to heteroskedasticity. In the cumulative abnormal returns and probability of deal completion regressions, we use White heteroskedastic consistent standard errors (White (1980)).

\section{Results}

Tables II through VI present the results for each dependent variable successively. Each table reports five specifications. Column (1) has the baseline model where both acquirer and target CEO narcissism are included. Columns (2) and (4) show the results when only the acquirer or target CEO narcissism is included. Columns (3) and (5) have the interaction between acquirer and target CEO narcissism, along with the acquirer and target.

Columns (2) and (4) essentially confirm the stability of the estimates. All results about narcissism variables reported in Column (1), the baseline model, are similar when acquirer and target CEO narcissism are introduced separately. Results concerning control variables are mostly unaffected. The specific choices of control variables do not appear to drive our results. 
Bid premium. Results for the bid premium are presented in Table II. The positive and significant coefficient for target CEOs narcissism in Column (1) suggests that narcissistic target CEOs are able to extract higher bid premiums from merger negotiations. This result still stands after controlling for the interaction between acquirer and target CEO narcissism (Column 5). The result is economically meaningful: in the baseline regression, a $10 \%$ increase in target CEO narcissism is associated with a $6.3 \%$ increase in the bid premium. This is consistent with the motivational aspect of narcissism emphasized by Chatterjee and Hambrick (2007): highly narcissistic target CEOs can maintain their self-image by obtaining a high premium for their shareholders, thereby compensating in some measure for the blow of losing independence.

At first glance, acquirer CEO narcissism does not seem to play a role (Column 1) but, after taking into account the interaction between acquirer and target CEOs (Column 3), another pattern emerges: acquirer CEO narcissism is negative and significant and the interaction term is positive and significant. In the absence of target CEO narcissism (if the target CEO has a narcissism score of zero), an increase in acquirer CEOs narcissism leads to a decrease in bid premium. The effect is, however, progressively offset by an increase in target CEO narcissism. The importance of the interplay between acquirer and target CEO narcissism is clearly highlighted, which is perhaps unsurprising given the nature of narcissism (see Section II).

$$
\text { (Insert Table II about here) }
$$

The results for the control variables are broadly consistent with existing literature. The coefficient on the GIM index variable is negative and significant, a result inconsistent with the idea that poorly governed firms are bidding systematically higher.

Acquirer cumulative abnormal returns. The results presented in Column (1) of Table III show that higher levels of target CEO narcissism are linked to more negative market reactions for the acquirer. The result is again robust to including the interaction variable (Column 5). It is also economically meaningful 
as a $10 \%$ increase in target CEO narcissism implies a $1.3 \%$ decrease in acquirer cumulative abnormal returns. It appears that investors anticipate that a highly narcissistic target CEO may get the acquiring firm to concede more value to target shareholders. These results are consistent with highly narcissistic target CEOs being perceived as manipulators who are able to put pressure on a less narcissistic acquirer to achieve a good price. The coefficient of acquirer CEO narcissism is positive, but insignificant. Hence, the baseline regression provides no evidence that an acquirer CEO's narcissism affects his or her own shareholders.

But taking into account the interaction between acquirer and target CEO narcissism (Column 3) again provides a more nuanced view of the acquirer CEO effect. In the absence of target CEO narcissism, an increase in acquirer CEO narcissism leads to an increase in acquirer CARs. So, in itself, acquirer CEO narcissism does not appear to be detrimental to shareholders. However, this effect is gradually counterbalanced as target CEO narcissism increases, as shown by the negative and significant interaction variable.

$$
\text { (Insert Table III about here) }
$$

The coefficients of the control variables are mostly in the expected direction. The negative coefficient for the GIM index suggests that more poorly governed firms tend to undertake value destroying transactions, a result consistent with Masulis, Wang, and Xie (2007). The coefficient for multiple bidders is negative and significant, a result consistent with Betton, Eckbo, and Thorburn (2009). The competition induced by the existence of multiple bidders is no doubt perceived by investors as a signal that the winning bidder might have to bid more aggressively to win the takeover contest.

Deal initiation. The probit estimation of factors associated with acquirer deal initiation is presented in Table IV. Column (1) provides the results when both acquirer and target CEO narcissism are entered into the model along with control variables. The positive and significant acquirer CEO narcissism shows that higher narcissism among acquiring CEOs increases the likelihood of the acquirer CEO 
initiating a deal. The result is economically significant: an estimation of the marginal effects shows that a $10 \%$ increase in acquirer CEO narcissism is associated with a $10 \%$ increase in the probability that the acquiring firm initiates the takeover process (unreported). The coefficient on target CEO narcissism is negative but not significant.

However, as in the case of the bid premium, controlling for the interaction between acquirer and target CEO narcissism reveals another story. In Column (5), the coefficient for target CEO narcissism is negative and significant: in the absence of acquirer narcissism, the probability that the target CEO initiates a transaction is, as expected, decreasing in target CEO narcissism. This effect is progressively offset by an increase in acquirer CEO narcissism.

$$
\text { (Insert Table IV about here) }
$$

These results are consistent with the idea that narcissistic acquiring CEOs are keen to undertake highly visible initiatives in order to nourish their need for ego-boosting admiration. However, the results also suggest that being a target is not all that ego- gratifying, even when one initiates the deal.

Private deal length. Table $\mathrm{V}$ presents the results of the negative binomial regression for the length of the private takeover process. As reported in Column (1), a higher degree of acquirer CEO narcissism is significantly associated with shorter takeover processes. As in the case of deal initiation, target CEO narcissism is insignificant in the baseline model but the inclusion of the interactions reveals a more subtle pattern of target CEO behavior. Target CEO narcissism is positive and significant in Column (5); in the absence of acquirer CEO narcissism, narcissistic target CEOs are in no hurry to clinch the deal. The increase in acquirer CEO narcissism progressively reverses this effect.

(Insert Table V about here)

The results for acquirer CEO narcissism are consistent with the motivational and interpersonally exploitative aspects of narcissism (American Psychiatric Association (1994), Campbell and Foster (2007)). 
Narcissists would be anxious to reap the ego benefits of a takeover announcement and would attempt to hurry to process along. Narcissistic target CEO behavior is likely driven by the desire to remain independent.

Several of the factors that are predicted by Jemison and Sitkin (1986) to influence the length of the private takeover process are significant in Table V. First, the coefficient on the acquirer GIM index is negative and significant, implying that poor governance quality is associated with a shorter negotiation time. This is consistent with the idea that poorly governed firms are unable to curb the actions of their CEOs. Second, acquirer acquisition experience is negative and significant. This conflicts with the predictions of Jemison and Sitkin (1986) who posit that prior experience could cause acquirers to be more careful, thereby slowing the process down. Finally, while Jemison and Sitkin (1986) include relative size as a factor influencing the length of the private takeover process, they do not make a specific prediction for the direction of its effect. In our results the coefficient on relative size is negative and significant, indicating that the greater the deal size compared to the acquirer's market value, the shorter the private takeover process.

Deal completion. Table VI reports the results. The negative and significant coefficients for bothacquirer and target CEO narcissism in Column (1) indicate more narcissism in either CEO reduces the likelihood of takeover completion. The negative effect of target CEO narcissism seems self-evident, since a highly narcissistic target CEO would be loath to lose independence. Also, negotiations would likely be difficult between two highly narcissistic executives. Interactions between acquirer and target CEO narcissism play no role here, as highlighted by the results in Columns (3) and (5). This is hardly surprising given that in the baseline regression, both CEO narcissism variables are pushing in the same direction.

$$
\text { (Insert Table VI about here) }
$$

Summary. Overall, the results point to four conclusions about CEO psychology in the M\&A context. First, although narcissism is generally considered a negative trait, it may have positive aspects. 
More narcissistic target CEOs are able to extract higher bid premiums, which is certainly good news for target shareholders. Narcissistic acquirer CEOs are able to more quickly conclude the private phase of the takeover process. This could also be worthwhile because it reduces negotiation costs. Further, an acquiring CEO who is highly narcissistic relative to the target CEO creates value, on average, for acquirer shareholders. Our findings are consistent with the theoretical insights of Maccoby (2000), who describes how productive narcissists can be a force for good at the head of firms, and Rosenthal and Pittinsky (2006), who provide examples of apparently narcissistic business leaders of firms that have performed excellently. Our results also echo research in finance on the positive effects of CEO overconfidence. While many studies show that it leads to poor outcomes, CEO overconfidence can be advantageous. It may energize CEOs to overcome their natural risk-aversion and undertake more risky or innovative projects with potentially higher returns to shareholders (Goel and Thakor (2008), Hirschleifer, Low, and Teoh (2010)).

Second, the effects of narcissism may be context-dependent. Our findings reveal that the effects of target and acquirer CEO narcissism differ according to the segment of the takeover process being analyzed. While in the baseline regressions higher levels of acquirer CEO narcissism are associated with a greater likelihood of deal initiation by the acquiring firm and with a shorter negotiation time, target CEO narcissism is associated with higher bid premiums and lower acquirer announcement returns. The probability of deal completion analyses are the only ones in which the narcissism of both CEOs has an effect in the same direction, which is to reduce the likelihood of the deal becoming effective. Our results echo the theoretical viewpoint of Rosenthal and Pittinsky (2006), who posit that "whether narcissists succeed or fail as leaders depends not only on their personalities, but also on the circumstances in which they lead" (p. 625). They are also consistent with the findings of Nevicka et al. (2011), who show, in an experimental setting, that the performance outcomes of narcissists are contextually dependent. 
Third, the results demonstrate the importance of accounting for both acquirer and target CEO characteristics in takeovers. A takeover involves interactions between two parties, so focusing on one ignoring the other could conceivably lead to an incorrect inference. Explicitly controlling for the interactions between acquirer and target CEOs narcissism reveals effects that would otherwise remain hidden in the data. This reflects the interpersonal implications of narcissism (American Psychiatric Association (1994), Campbell and Foster (2007)).

Finally, the findings show the necessity for a precise understanding of the psychological concept being studied. Our finding that acquirer cumulative abnormal returns are affected by target CEO narcissism but not by acquirer CEO narcissism might at first glance to seem inconsistent with Malmendier and Tate (2008) and John, Liu, and Taffler (2011). However, these two papers study overconfidence, a cognitive bias, and there is no reason to expect the same results for a personality trait such as narcissism. "CEO psychology" is indeed multifaceted.

\section{Robustness Checks}

This section describes and discusses robustness checks for various potential difficulties. For brevity, the robustness checks are not tabulated. They are available upon request from the authors.

\section{A. Robustness of the Narcissism Measure}

Our robustness checks of the narcissism measure aim to assess three potential problems. First, we verify the robustness of the first person pronoun score to biases which may arise from the methods used to compute it. Second, we check that our narcissism measure is consistent with others that have been applied in large samples. Finally, we examine whether we are really capturing the personality trait of narcissism rather than some other concept, such as overconfidence.

The narcissism variable has a positive and significant correlation with the amount of text used in its estimation. To neutralize the possible effect of text length, we create a second narcissism construct, 
residuals from a cross-CEO regression of narcissism on the number of text characters. Untabulated results show that all findings are robust to the adjusted narcissism measure.

We test the consistency of the narcissism measure with reference to Chatterjee and Hambrick (2007). The authors estimate a narcissism measure using an index, which includes the first person pronoun measure. Chatterjee and Hambrick (2007) find a positive and significant correlation between the first person pronoun measure and the other items in their index, including a measure of relative pay. We therefore check that the narcissism score among CEOs in our sample is also positively correlated with a relative pay measure. The required data are obtained from Execucomp, which restricts the sample to acquirer CEOs, as data are not available in Execucomp for most target CEOs. The relative pay measure is the acquirer CEO's total compensation divided by that of the next best paid officer. We are able to estimate the relative pay measure for 300 CEO-years, and find a mean of 2.45 . We then regress CEO total narcissism on the relative pay measure and find a positive and significant relation, thereby demonstrating consistency with existing research. This result is also robust to the inclusion of year fixed effects.

To test whether our narcissism measure is not just capturing overconfidence by another name, we compare it to the stock-options holding measure of overconfidence used in existing literature. Following John, Liu, and Taffler (2011), we estimate the average exercise price of each CEO's stock options portfolio using Execucomp data for each year of the sample period (2002-2006). A CEO is deemed "overconfident" in a given year according to whether he or she does not exercise stock options although they are $67 \%$ or more in the money. We classify a CEO as overconfident if he or she fails to exercise inthe-money stock options above the threshold during three out of the five years of the sample period. ${ }^{12}$ We are able to estimate this overconfidence measure for 94 acquirer CEOs in our sample. We assign

\footnotetext{
${ }^{12}$ We err on the side of caution compared to John, Liu, and Taffler (2011), who only require two years of overconfident stock options holding behavior to classify a CEO as "overconfident". Alternative specifications give similar results.
} 
acquirer CEOs to two groups, overconfident and non-overconfident CEOs, then estimate the mean narcissism score for each group, and calculate the statistical significance of the difference. The difference is statistically indistinguishable from zero ( $t$-stat: 0.66 ), implying that overconfident and nonoverconfident CEOs identified using the stock options holding measure are equally narcissistic. This suggests that we are capturing something other than overconfidence with the first person pronoun measure.

\section{B. Simultaneity Issues}

Our deal initiation results are potentially compromised because the decision to initiate a deal is likely endogenous to the choice of a selling procedure (auction versus negotiation), at least to some extent. Examples of latent factors correlated to both initiation and the selling procedure choice are sometimes suggested in the merger background section of the SEC filings. For example, a board member of a target firm may know a potential advisor, leading the board to contact this advisor to organize an auction when the decision to sell the firm is taken. Alternatively, a board member of a target firm may know a CEO or a director of another firm, making a negotiation the likely selling procedure. The presence of these latent variables may bias coefficient estimates of the deal initiation determinants. We correct for this potential issue using a bivariate probit model (see Greene (2008), p. 817), which is suitable for the simultaneous estimation of two equations whose dependent variable is dichotomous. Estimates are obtained by log-likelihood function maximization. The unreported results of the bivariate probit analysis confirm our original results for deal initiation, with a positive and significant coefficient ( $p$ value $=0.02$ ) on the acquirer CEO narcissism variable.

\section{Other Potential Issues}

This section covers three other issues that could potentially confound our measure of CEO narcissism. First, we consider the possibility that the results may be attributable to agency problems 
instead of to CEO narcissism. If the narcissism variable picks out CEOs prone to agency-driven issues, then a supposedly narcissistic CEO might be more inclined to undertake value destroying deals (i.e., deals with negative synergies) to gain private benefits or to reinforce an entrenched position. To test whether the agency-related effect is present, we use the deal cumulative abnormal returns as a proxy for merger synergies and regress it on acquirer CEO narcissism. If we are in fact picking up agency-related problems, we would expect a negative and significant coefficient on the acquirer CEO narcissism variable. Our results show that the coefficient is positive and non-significant ( $p$-value $=0.3$ ).

A second issue with the narcissism measure is that, in the case of target CEOs, it could simply be proxying for takeover resistance. To examine this point, we regress target CEO narcissism on target GIM index for the years 2002, 2004 and 2006, giving us a total of 165 CEO-years for analysis. If target CEO narcissism reflects takeover resistance, we expect a positive and significant coefficient on the target CEO narcissism variable. The coefficient is insignificant ( $p$-value $=0.88$ ), which tends to alleviate the concern that we are in fact picking up takeover resistance.

Finally, we address the issue of the stability of the narcissism measure over time. One might argue that the fact of being involved in a takeover process could cause a simultaneous increase in acquirer CEO narcissism and decrease in target CEO narcissism which could exacerbate some of the effects we observe in our paper. To check this point, we estimate the first person pronoun measure for a sample of acquirer and target CEOs for the year before the beginning of the takeover process and the year in which the process began. We estimate the mean narcissism score for acquirer and target CEOs in each of the years, and calculate the difference in means between the narcissism score in the year before the process began and the year the takeover process began. In the case of both target and acquirer CEOs, the difference in means is indistinguishable from zero ( $t$-stats 0.52 and 0.17 respectively). 


\section{Conclusion}

We study the effect of target and acquirer CEO narcissism on the takeover process. Highly narcissistic individuals need to continuously reinforce their ego (Buss and Chiodo (1991), Chatterjee and Hambrick (2007)), a need that seems likely to be on full display during large stakes initiatives such as takeovers. Narcissists are also manipulative and lack empathy (American Psychiatric Association (1994)), which is surely relevant for bargaining between two CEOs. Narcissism is a well-defined psychological concept that has a validated indirect measure.

We examine the effects of target and acquirer CEO narcissism on the bid premium, the acquirer cumulative abnormal returns, the identity of the initiating party, the length of the private takeover process, and the probability of deal completion. Our main findings are as follows: (i) the bid premium is positively related to target CEO narcissism; (ii) acquirer cumulative abnormal returns are negatively related to target CEO narcissism; (iii) the probability of initiation by the acquiring firm is positively related to acquirer CEO narcissism; (iv) the length of the private takeover process is negatively related to acquirer CEO narcissism; (v) the probability of deal completion is negatively related to both acquirer and target CEO narcissism; and (vi) in most cases, interactions between acquirer and target CEO narcissism matter, reinforcing (or mitigating) the observed effects.

These findings lead to four general conclusions. First, they suggest that although narcissism is often considered a negative trait, it may have positive aspects such as the positive association between target CEO narcissism and the bid premium. Second, the effects of CEO narcissism are context dependent, as shown by the differing results for target and acquirer CEO narcissism and for their effects on the various portions of the takeover process. Third, our findings highlight the importance of including the characteristics of both acquirer and target CEOs in order to fully document the effects of CEO psychology on the takeover process. Finally, we believe that a thorough understanding of the psychological construct being studied is required to interpret the empirical results correctly. 


\section{References}

Aktas, Nihat, Eric de Bodt, and Richard Roll, 2010, Negotiations under the threat of an auction, Journal of Financial Economics 98, 241-255.

American Psychiatric Association, 1994. Diagnostic and Statistical Manual of Mental Disorders (4th Edition, Washington, DC: Author).

Bates, Thomas W., and Michael L. Lemmon, 2003, Breaking up is hard to do? An analysis of termination fee provisions and merger outcomes, Journal of Financial Economics 69, 469-504.

Betton, Sandra, B. Espen Eckbo, and Karin S. Thorburn, 2008, Corporate takeovers, in B. Espen Eckbo, ed.: Handbook of Corporate Finance: Empirical Corporate Finance (Elsevier, North-Holland).

Betton, Sandra, B. Espen Eckbo, and Karin S. Thorburn, 2009, Merger negotiations and the toehold puzzle, Journal of Financial Economics 91, 158-178.

Bhagat, Sanjai, Ming Dong, David A. Hirshleifer, and Robert B. Noah, 2005, Do tender offers create value? New methods and evidence, Journal of Financial Economics 60, 3-60.

Boone, Audra L., and J. Harold Mulherin, 2007, How are firms sold? Journal of Finance 62, 847-875.

Boone, Audra L. and J. Harold Mulherin, 2009, Is there one best way to sell a company? Auctions versus negotiations and controlled sales, Journal of Applied Corporate Finance 21, 28-37.

Buss, David M., and Lisa M. Chiodo, 1991, Narcissistic acts in everyday life, Journal of Personality 59, 179-215.

Campbell, W. Keith, and, Joshua D. Foster, 2007, The narcissistic self: Background, and extended agency model, and ongoing Controversies, in: Constantine Sedikides and Steven J. Spencer, ed.: The Self, Frontiers of Social Psychology (New York: Psychology Press).

Chatterjee, Arijit, and Donald C. Hambrick, 2007, It's all about me: Narcissistic chief executive officers and their effects on company strategy and performance, Administrative Science Quarterly 52, 351386.

Coff, Russell W., 1999, How buyers cope with uncertainty when acquiring firms in knowledge-intensive industries: Caveat emptor, Organization Science 10, 144-161.

Emmons, Robert A., 1987, Narcissism: Theory and measurement, Journal of Personality and Social Psychology 52, 11-17.

Fich, Eliezer M., Jie Cai, and Anh L. Tran, 2011, Stock option grants to target CEOs during private merger negotiations, Journal of Financial Economics 101, 413-430.

Freud, Sigmund, 1914, On narcissism: An introduction, in Andrew P. Morrison, ed.: Essential Papers on Narcissism (New York University Press).

Fuller, Kathleen, Jeffry Netter, and Mike Stegemoller, 2002, What Do returns to acquiring firms tell us? Evidence from firms that make many acquisitions, Journal of Finance 57, 1763-1793.

Goel, Anand M., and Anjan V. Thakor, 2008, Overconfidence, CEO selection, and corporate governance, Journal of Finance 63, 2737-2784.

Goel, Anand M., and Anjan V. Thakor, 2010, Do envious CEOs cause merger waves? Review of Financial Studies 23, 487-517.

Gompers, Paul A., Joy L. Ishii, and Andrew Metrick, 2003, Corporate governance and equity prices, 
Quarterly Journal of Economics 118, 107-155.

Greene, William, 2008. Econometric Analysis (Sixth Edition, Prentice Hall).

Guo, Shourun, Edith S. Hotchkiss, and Weihong Song, 2011, Do buyouts (still) create value? Journal of Finance 66, 479-517.

Hansen, Robert G., 2001, Auctions of companies, Economic Inquiry 24, 125-142.

Hayward, Mathew L. A., and Donald C. Hambrick, 1997, Explaining the premiums paid for large acquisitions: Evidence of CEO hubris, Administrative Science Quarterly 42, 103-127.

Hirshleifer, David A., Angie Low, and Siew Hong Teoh, 2010, Are overconfident CEOs better innovators? Unpublished manuscript available at SSRN: http://ssrn.com/abstract=1598021.

Horowitz, Joel L., 2001. The bootstrap, in James J. Heckman and Edward Leamer, ed.: Handbook of Econometrics Volume 5. (Elsevier).

Jemison, David B., and Sim B. Sitkin, 1986, Corporate acquisitions: A process perspective. Academy of Management Review 11, 145-163.

John, Kose, Liu, Lucy, and Richard Taffler, 2011, It takes two to tango: Overpayment and value destruction in M\&A deals, Unpublished manuscript, New York University.

Kets de Vries, Manfred F.R., and Danny Miller, 1985, Narcissism and leadership: An object relations perspective, Human Relations 38, 583-601.

$\mathrm{Li}$, Jiatao, and Yi Tang, 2010, CEO hubris and firm risk taking in China: The moderating role of managerial discretion, Academy of Management Journal 53, 45-68.

Luo, Yuanzhi, 2005. Do insiders learn from outsiders? Evidence from mergers and acquisitions, Journal of Finance 60, 1951-1982.

Maccoby, Michael, 2000, Narcissistic leaders: The incredible pros, the inevitable cons, Harvard Business Review (Jan - Feb), 69-77.

Malmendier, Ulrike, and Geoffrey Tate, 2005, CEO overconfidence and corporate investment, Journal of Finance 60, 2661-2700.

Malmendier, Ulrike, and Geoffrey Tate, 2008, Who makes acquisitions? CEO overconfidence and the market's reaction, Journal of Financial Economics 89, 20-43.

Malmendier, Ulrike, Geoffrey Tate, and Jonathan Yan, 2011, Overconfidence and early-life experiences: The effect of managerial traits on corporate financial policies, Journal of Finance 66, 1687-1733.

Masulis, Ronald W., Cong Wang, and Fei Xie, 2007, Corporate governance and acquirer returns, Journal of Finance 62, 1851-1889.

Moeller, Sara B., Frederik P. Schlingemann, and René M. Stulz, 2005, Wealth destruction on a massive scale? A study of acquiring-firm returns in the recent merger wave, Journal of Finance 60, 757782.

Moore, Don, and Paul J. Healy, 2008, The trouble with overconfidence, Psychological Review 115, 502517.

Nevicka, Barbora, Annabel H.B. De Hoogh, Annelies E.M. Van Vianen, Bianca Beersma, and Doris Mcllwain, 2011, All I need is a stage to shine: Narcissists' leader emergence and performance, Leadership Quarterly 22, 910-925. 
Owen, David, and Jonhatan Davidson, 2009, Hubris syndrome: An acquired personality disorder? A study of US Presidents and UK Prime Ministers over the last 100 years, Brain 132, 1396-1406.

Raskin, Robert, and Calvin S. Hall, 1979, A narcissistic personality inventory, Psychological Reports 45, 590.

Raskin, Robert, and Calvin S. Hall, 1981, The narcissistic personality inventory: Alternative form reliability and further evidence of construct validity, Journal of Personality Assessment 45, 159-162.

Raskin, Robert, and Robert Shaw, 1988, Narcissism and the use of personal pronouns, Journal of Personality 56, 393-404.

Roll, Richard, 1986, The hubris hypothesis of corporate takeovers, Journal of Business 59, 197-216.

Rosenthal, Seth A., and Todd L. Pittinsky, 2006, Narcissistic leadership. Leadership Quarterly 17, 617-633.

Schlingemann, Frederik P., René M. Stulz, and Ralph A. Walkling, 2002, Divestitures and the liquidity of the market for corporate assets, Journal of Financial Economics 64, 117-144.

Simsir, Serif Aziz, 2009, The information content of deal initiation in mergers and acquisitions, Unpublished manuscript, Sabanci University.

White, Halbert, 1980, A heteroskedasticity-consistent covariance matrix estimator and a direct test for heteroskedasticity, Econometrica 48, 817-838. 


\section{Appendix A. Diagnostic Criteria for Narcissistic Personality Disorder}

A pervasive pattern of grandiosity (in fantasy or behavior), need for admiration, and lack of empathy, beginning by early adulthood and present in a variety of contexts, as indicated by five (or more) of the following:

(1) has a grandiose sense of self-importance (e.g., exaggerates achievements and talents, expects to be recognized as superior without commensurate achievements)

(2) is preoccupied with fantasies of unlimited success, power, brilliance, beauty, or ideal love

(3) believes that he or she is "special" and unique and can only be understood by, or should associate with, other special or high-status people (or institutions)

(4) requires excessive admiration

(5) has a sense of entitlement, i.e., unreasonable expectations of especially favorable treatment or automatic compliance with his or her expectations

(6) is interpersonally exploitative, i.e., takes advantage of others to achieve his or her own ends

(7) lacks empathy: is unwilling to recognize or identify with the feelings and needs of others

(8) is often envious of others or believes that others are envious of him or her

(9) shows arrogant, haughty behaviors or attitudes

NOTE: italics identify those items which overlap with the symptoms of hubris syndrome.

Source: DSM IV, Diagnostic and Statistical Manual of Mental Disorders, fourth edition, 1994. 301.81, p. 717. 


\section{Appendix B. Variable Definitions}

\begin{tabular}{|c|c|}
\hline Variable & Description \\
\hline \multicolumn{2}{|l|}{ Panel A. CEO narcissism } \\
\hline Acquirer CEO narcissism & $\begin{array}{l}\text { Total number of first person singular pronouns divided by total number of } \\
\text { first person pronouns used in acquirer CEO speech. CEO speech is } \\
\text { obtained from interviews available on the Lexis Nexis Academic database. }\end{array}$ \\
\hline Target CEO narcissism & $\begin{array}{l}\text { Total number of first person singular pronouns divided by total number of } \\
\text { first person pronouns used in target CEO speech. CEO speech is obtained } \\
\text { from interviews available on the Lexis Nexis Academic database. }\end{array}$ \\
\hline \multicolumn{2}{|l|}{ Panel B. Dependent variables } \\
\hline Acquirer initiated dummy & $\begin{array}{l}\text { Dummy variable: } 1 \text { if the acquirer initiated the deal, zero otherwise. } \\
\text { Information is collected from the merger background section of the } \\
\text { relevant SEC filing. }\end{array}$ \\
\hline $\begin{array}{l}\text { Private takeover process } \\
\text { length }\end{array}$ & $\begin{array}{l}\text { The number of months elapsed between the beginning of the deal } \\
\text { process and the SDC announcement date. Information is collected from } \\
\text { the merger background section of the relevant SEC filing. }\end{array}$ \\
\hline Bid premium & $\begin{array}{l}\text { The SDC four-week premium: the share price offered by the winning } \\
\text { bidder to target shareholders deflated by the price of the target four } \\
\text { weeks prior to the announcement date. }\end{array}$ \\
\hline Acquirer CARs & $\begin{array}{l}\text { Acquirer cumulative abnormal returns from day }-5 \text { to day }+5 \text {, relative to } \\
\text { the announcement date. Daily abnormal returns are from the Beta-one } \\
\text { model, which subtracts the daily market portfolio return from the daily } \\
\text { return of each firm. }\end{array}$ \\
\hline $\begin{array}{l}\text { Ex-ante probability of deal } \\
\text { completion }\end{array}$ & $\begin{array}{l}\text { Target cumulative abnormal returns from day }-5 \text { to day }+5 \text {, relative to the } \\
\text { announcement date, divided by the SDC one-week bid premium. }\end{array}$ \\
\hline \multicolumn{2}{|l|}{ Panel C. Control variables } \\
\hline \multicolumn{2}{|l|}{ Deal characteristics } \\
\hline Selling procedure dummy & $\begin{array}{l}\text { Dummy variable: } 1 \text { if the deal is an auction (i.e., more than one potential } \\
\text { bidder is mentioned in the merger background section of the relevant SEC } \\
\text { filing); } 0 \text { otherwise. }\end{array}$ \\
\hline Relative deal size & $\begin{array}{l}\text { Ratio of deal size (total value of the consideration paid by the acquirer, } \\
\text { excluding fees and expenses) to acquirer size. }\end{array}$ \\
\hline Deal size & Total value of consideration paid by the acquirer (\$ million) \\
\hline Cash dummy & Dummy variable: 1 if the payment is exclusively in cash, 0 otherwise. \\
\hline Multiple bidders dummy & $\begin{array}{l}\text { Dummy variable: } 1 \text { if more than one potential bidder is mentioned in the } \\
\text { Background to the merger section of the relevant SEC filing. }\end{array}$ \\
\hline Horizontal deal dummy & $\begin{array}{l}\text { Dummy variable: } 1 \text { for deal in which both the bidder and the target are in } \\
\text { the same Fama-French industry (using the } 49 \text { industry classification } \\
\text { scheme). }\end{array}$ \\
\hline Liquidity index & $\begin{array}{l}\text { Computed as in Schlingemann, Stulz, and Walkling (2002) at the two-digit } \\
\text { SIC code level for each year. It corresponds to the ratio of the value of } \\
\text { corporate control transactions in a year to the total book value of assets } \\
\text { of firms in the same two-digit SIC code during that year. }\end{array}$ \\
\hline
\end{tabular}




\begin{tabular}{|c|c|}
\hline \multicolumn{2}{|l|}{ Firm characteristics } \\
\hline Acquirer GIM index & $\begin{array}{l}\text { Gompers, Ishii, and Metrick (2003) corporate governance quality index. } \\
\text { Higher index levels correspond to lower quality governance. }\end{array}$ \\
\hline Acquirer size & $\begin{array}{l}\text { Market value of acquirer equity (number of shares outstanding multiplied } \\
\text { by the stock price) at day }-42 \text { relative to the announcement date in } \\
\text { billions of dollars. The regressions use the natural log of this variable. }\end{array}$ \\
\hline Acquirer leverage & Total of long term debt plus current debt divided by total assets. \\
\hline Acquirer in regulated industry & $\begin{array}{l}\text { Dummy variable: } 1 \text { if the acquirer is in a regulated industry (SIC codes } 48 \text { - } \\
49 ; 60-69 \text { ). }\end{array}$ \\
\hline Acquirer M\&A experience & $\begin{array}{l}\text { Number of deals carried out by the acquiring firm over the previous } 24 \\
\text { months prior to the announcement date. To construct this variable, we } \\
\text { considered a sample of M\&A deals that included public, private, U.S., and } \\
\text { non-U.S. targets with a deal size above } \$ 1 \text { million and equal to at least } 1 \% \\
\text { of the acquirer's market value. }\end{array}$ \\
\hline Target size & $\begin{array}{l}\text { Market value of target equity (number of shares outstanding multiplied by } \\
\text { the stock price) at day }-42 \text { relative to the announcement date in billions } \\
\text { of dollars. The regressions use the natural log of this variable. }\end{array}$ \\
\hline Target runup & $\begin{array}{l}\text { Target average cumulative abnormal return over the period }[-42,-6] \\
\text { using a value-weighted market model following Betton, Eckbo, and } \\
\text { Thorburn (2009). }\end{array}$ \\
\hline Target turnover & $\begin{array}{l}\text { Following Betton, Eckbo, and Thorburn (2009), target turnover is } \\
\text { estimated as the average daily trading volume as a fraction of target } \\
\text { shares over the period }[-166,-42) \text {. }\end{array}$ \\
\hline Target NYSE/AMEX listed & $\begin{array}{l}\text { Dummy variable: } 1 \text { if the target firm is listed on the NYSE or AMEX } \\
\text { exchanges; } 0 \text { otherwise. }\end{array}$ \\
\hline Concentration target sales & $\begin{array}{l}\text { The Herfindahl-Hirschman concentration index of the target's sales (the } \\
\text { sum of squares of sales shares by business segments). Sales by business } \\
\text { segment are obtained using the Compustat Segment database. }\end{array}$ \\
\hline Private target & Dummy variable: 1 if the target is a private firm and 0 otherwise. \\
\hline
\end{tabular}




\section{Appendix C. Sample of CEO Speech after Cleaning}

FD (Fair Disclosure) Wire May 9, 2006 Tuesday Q1 2006 Kos Pharmaceuticals Earnings Conference Call - Final. Source: Lexis-Nexis Academic database ${ }^{13}$

CEO: Adrian Adams. This excerpt represents 641 words out of a total 5,202 words spoken by the CEO during this conference call. We have 9 transcripts of this type for Adrian Adams. Highlighting identifies first person pronouns which are used to estimate the first person pronoun based narcissism measure.

$$
\text { ../.. }
$$

Well, as you know, I think that we presented the top line data in our last earnings release. Obviously, our key focus is to get this data published, and obviously the reason we've not shared the overall results is not to prejudice that publication, so we anticipate that data being published during the second half of this year, and we're looking forward to the rollout of that optimized formulation in the first quarter of next year, and as you know, the results overall showed a $41 \%$ reduction in the overall severity of flush and a 42 to $43 \%$ reduction in the duration of flush, significance of the .0001 level, so we're excited about the data. We anticipate launching that formulation during the next few months. We are very excited about 1040 milligram strength. The overall goal in dislipidemia therapy, and with our strategy with our customers, is to get more and more patients up to the highest effective dose, that gives them the protection that they require, and the life saving benefits that are offered. And we believe that the 1040 milligram strength of Advicor, which by the way, was the dose that was used in the [Advocare] study, which demonstrated superiority over Lipitor and Zocor. We believe that that is going to help us even broaden further the Advicor patient base with regard to, the impact and overall financials, obviously, would not given specific guidance in relation to Advicor, but we'll certainly, this will allow more patients to get, not just Advicor therapy, but also a more effective dose, so we're very excited about it and I think that our doctors will be as well.

The trial that we presented? Yes, obviously it's already done and we're focused on, obviously, publishing that and we will be submitting the sNDA for that during the early part of the third quarter. We anticipate this will be a relatively simple turnaround with the FDA, hence our confidence in rolling out this new formulation in the early part of next year. I would also like to emphasize, in keeping with our good success over the course of time, I think we have ongoing life cycle management initiatives in support of our overall business strategy, and I'll be communicating those over the course of the next year or so.

In terms of providing the earning break down for the quarter?

Yes. Niaspan, for the quarter, was on a reported basis, about 100 million, and Advicor about 23.5.

You're welcome.

I'll cover the second part of that question. As we mentioned during the call, the CMS initial decision that was made towards the end of last year, we believe, did have an impact on prescribing trends during the first quarter of this year. Interestingly enough, part D, we believe, actually had a positive impact on prescription trends in the chronic disease area. In fact if you look at the trends in the cholesterol market, more specifically, we saw an increase in growth of that market as it moved into the first part of this year, or like the second half of last year. Because of the CMS decision we were not able to participate in the growth. In addition to that, some of the patients that obviously were on Niaspan, perhaps, wouldn't be covered under part D started to switch to other plans, and we believe that is one of the reasons why our prescription trend during the first quarter of this year softer than anticipated. Having got a positive decision from CMS, and this was a great win for Kos, and indeed, patients and doctors, we've obviously optimistic that prescribing trends will get better and in the end, nothing is changed in relation to our highly differentiated position and obviously all of the data in relation to clinical trends is moving in our favor.

../..

\footnotetext{
${ }^{13}$ Copyright 2006 Voxant, Inc. All Rights Reserved; Copyright 2006 CCBN, Inc. All Rights Reserved.
} 
Table I

\section{Summary Statistics}

This table reports summary statistics for our sample of acquisitions. Our sample of acquisitions covers deals announced over the period 2002 to 2006 and is extracted from the Securities Data Company's (SDC) US Mergers and Acquisitions Database. The extraction criteria used are presented in Section II.A. For dummy variables the table displays only the mean, which corresponds to the proportion of the variable. Variable definitions are in Appendix B. Panel A focuses on CEO narcissism, which is the variable of interest. Panel B provides summary statistics of the dependent variables characterizing the deal process. Panel $C$ displays summary statistics for the control variables grouped in terms of deal and firm characteristics. $N$ denotes the sample size.

\begin{tabular}{|c|c|c|c|c|c|}
\hline Variable & Mean & Median & Minimum & Maximum & $\mathrm{N}$ \\
\hline \multicolumn{6}{|l|}{ Panel A. CEO narcissism } \\
\hline Acquirer CEO narcissism & 0.215 & 0.204 & 0.076 & 0.449 & 146 \\
\hline Target CEO narcissism & 0.185 & 0.166 & 0.008 & 0.432 & 146 \\
\hline \multicolumn{6}{|l|}{ Panel B. Dependent variables } \\
\hline Acquirer initiated dummy & $60.27 \%$ & & & & 146 \\
\hline Private takeover process length (months) & 7.30 & 6.00 & 0.00 & 25.00 & 144 \\
\hline Bid premium & $36.14 \%$ & $27.57 \%$ & $-14.64 \%$ & $200.67 \%$ & 141 \\
\hline Acquirer CARs & $-1.67 \%$ & $-0.95 \%$ & $-22.75 \%$ & $26.67 \%$ & 143 \\
\hline Ex-ante probability of deal completion & $77.27 \%$ & $82.88 \%$ & $1.51 \%$ & $204.65 \%$ & 123 \\
\hline \multicolumn{6}{|l|}{ Panel C. Control variables } \\
\hline \multicolumn{6}{|l|}{ Deal characteristics } \\
\hline Auction dummy & $50.68 \%$ & & & & 146 \\
\hline Relative deal size & 0.35 & 0.13 & 0.01 & 3.78 & 146 \\
\hline Deal size (\$M) & 3,631 & 959 & 40 & 58,760 & 146 \\
\hline Cash dummy & $40.10 \%$ & & & & 146 \\
\hline Multiple bidders dummy & $34.48 \%$ & & & & 145 \\
\hline Horizontal deal dummy & $64.08 \%$ & & & & 142 \\
\hline Liquidity index & $3.77 \%$ & $1.99 \%$ & $0.00 \%$ & $36.40 \%$ & 142 \\
\hline \multicolumn{6}{|l|}{ Firm characteristics } \\
\hline Acquirer GIM index & 9.47 & 9.00 & 3.00 & 16.00 & 129 \\
\hline Acquirer size (market value in $\$ B n$ ) & 16.60 & 6.95 & 0.25 & 137.23 & 143 \\
\hline Acquirer leverage & 0.21 & 0.18 & 0.00 & 0.79 & 143 \\
\hline Acquirer in regulated industry & $25.17 \%$ & & & & 143 \\
\hline Acquirer M\&A experience & 0.39 & 0.00 & 0.00 & 5.00 & 143 \\
\hline Target size (market value in $\$ B n$ ) & 2.90 & 0.71 & 0.037 & 48.28 & 136 \\
\hline Target runup & $1.93 \%$ & $1.43 \%$ & $-40.81 \%$ & $44.13 \%$ & 136 \\
\hline Target turnover & 10.55 & 8.35 & 0.72 & 82.55 & 136 \\
\hline Target NYSE/AMEX listed & $30.88 \%$ & & & & 136 \\
\hline Concentration target sales & 0.62 & 0.50 & 0.16 & 1.00 & 136 \\
\hline
\end{tabular}


Table II

The Bid Premium and CEO Narcissism

This table reports ordinary least square regressions with the bid premium as dependent variable. The sample of acquisitions covers deals announced over the period 2002 to 2006 and is extracted from the Securities Data Company's (SDC) U.S. Mergers and Acquisitions Database. The extraction criteria are presented in Section II.A. Variable definitions are in Appendix B. P-values, reported between parentheses, are bootstrapped according to the method described in Section II.C.

\begin{tabular}{|c|c|c|c|c|c|}
\hline Variable & (1) & $(2)$ & (3) & (4) & (5) \\
\hline Intercept & $\begin{array}{l}0.694 \\
(0.00)\end{array}$ & $\begin{array}{l}0.788 \\
(0.00)\end{array}$ & $\begin{array}{l}0.811 \\
(0.00)\end{array}$ & $\begin{array}{l}0.611 \\
(0.00)\end{array}$ & $\begin{array}{l}0.637 \\
(0.00)\end{array}$ \\
\hline Acquirer CEO narcissism & $\begin{array}{r}-0.273 \\
(0.23)\end{array}$ & $\begin{array}{r}-0.231 \\
(0.25)\end{array}$ & $\begin{array}{r}-0.776 \\
(0.03)\end{array}$ & & \\
\hline Target CEO narcissism & $\begin{array}{l}0.634 \\
(0.03)\end{array}$ & & & $\begin{array}{l}0.620 \\
(0.03)\end{array}$ & $\begin{array}{l}0.915 \\
(0.03)\end{array}$ \\
\hline Acquirer CEO x Target CEO narcissism & & & $\begin{array}{l}2.660 \\
(0.05)\end{array}$ & & $\begin{array}{r}-1.376 \\
(0.25)\end{array}$ \\
\hline Target size & $\begin{array}{r}-0.046 \\
(0.01)\end{array}$ & $\begin{array}{r}-0.042 \\
(0.01)\end{array}$ & $\begin{array}{r}-0.046 \\
(0.01)\end{array}$ & $\begin{array}{r}-0.046 \\
(0.01)\end{array}$ & $\begin{array}{r}-0.046 \\
(0.01)\end{array}$ \\
\hline Target runup & $\begin{array}{l}0.435 \\
(0.03)\end{array}$ & $\begin{array}{l}0.426 \\
(0.03)\end{array}$ & $\begin{array}{l}0.433 \\
(0.03)\end{array}$ & $\begin{array}{l}0.432 \\
(0.03)\end{array}$ & $\begin{array}{l}0.435 \\
(0.03)\end{array}$ \\
\hline Turnover & $\begin{array}{l}0.001 \\
(0.35)\end{array}$ & $\begin{array}{l}0.001 \\
(0.34)\end{array}$ & $\begin{array}{l}0.001 \\
(0.36)\end{array}$ & $\begin{array}{l}0.001 \\
(0.33)\end{array}$ & $\begin{array}{l}0.001 \\
(0.34)\end{array}$ \\
\hline Target NYSE/AMEX listed & $\begin{array}{r}-0.066 \\
(0.22)\end{array}$ & $\begin{array}{r}-0.065 \\
(0.21)\end{array}$ & $\begin{array}{r}-0.071 \\
(0.18)\end{array}$ & $\begin{array}{r}-0.063 \\
(0.21)\end{array}$ & $\begin{array}{r}-0.064 \\
(0.21)\end{array}$ \\
\hline Acquirer GIM index & $\begin{array}{r}-0.023 \\
(0.03)\end{array}$ & $\begin{array}{r}-0.024 \\
(0.02)\end{array}$ & $\begin{array}{r}-0.023 \\
(0.03)\end{array}$ & $\begin{array}{r}-0.020 \\
(0.03)\end{array}$ & $\begin{array}{r}-0.023 \\
(0.03)\end{array}$ \\
\hline Cash dummy & $\begin{array}{l}0.171 \\
(0.00)\end{array}$ & $\begin{array}{l}0.190 \\
(0.00)\end{array}$ & $\begin{array}{l}0.171 \\
(0.00)\end{array}$ & $\begin{array}{c}0.166 \\
(0.00)\end{array}$ & $\begin{array}{l}0.172 \\
(0.00)\end{array}$ \\
\hline Multiple bidders dummy & $\begin{array}{r}-0.037 \\
(0.30)\end{array}$ & $\begin{array}{r}-0.046 \\
(0.23)\end{array}$ & $\begin{array}{r}-0.035 \\
(0.30)\end{array}$ & $\begin{array}{r}-0.032 \\
(0.38)\end{array}$ & $\begin{array}{r}-0.039 \\
(0.29)\end{array}$ \\
\hline Horizontal deal & $\begin{array}{l}0.085 \\
(0.04)\end{array}$ & $\begin{array}{r}0.076 \\
(0.03)\end{array}$ & $\begin{array}{l}0.078 \\
(0.04)\end{array}$ & $\begin{array}{l}0.087 \\
(0.03)\end{array}$ & $\begin{array}{l}0.088 \\
(0.03)\end{array}$ \\
\hline Number of observations & 123 & 123 & 123 & 123 & 123 \\
\hline Adjusted $\mathrm{R}^{2}$ & 0.231 & 0.212 & 0.226 & 0.234 & 0.231 \\
\hline F stat & 4.662 & 4.654 & 4.569 & 5.137 & 4.669 \\
\hline
\end{tabular}


Table III

\section{Acquirer Announcement CARs and CEO Narcissism}

This table reports ordinary least square regressions where the dependent variable is the 11-day acquirer cumulative abnormal returns (CARs), centered on the announcement day. The sample of acquisitions covers deals announced over the period 2002 to 2006 and is extracted from the Securities Data Company's (SDC) U.S. Mergers and Acquisitions Database. The extraction criteria are presented in Section II.A. Variable definitions are in Appendix B. P-values, reported between parentheses, are estimated using White heteroskedastic-consistent standard errors and are bootstrapped according to the method described in Section II.C.

\begin{tabular}{|c|c|c|c|c|c|}
\hline Variable & (1) & $(2)$ & (3) & (4) & (5) \\
\hline \multirow[t]{2}{*}{ Intercept } & 0.072 & 0.053 & 0.048 & 0.088 & 0.083 \\
\hline & $(0.12)$ & (0.19) & $(0.21)$ & $(0.07)$ & $(0.08)$ \\
\hline \multirow[t]{2}{*}{ Acquirer CEO narcissism } & 0.052 & 0.044 & 0.155 & & \\
\hline & $(0.23)$ & $(0.27)$ & (0.09) & & \\
\hline \multirow[t]{2}{*}{ Target CEO narcissism } & -0.130 & & & -0.127 & -0.186 \\
\hline & $(0.04)$ & & & $(0.03)$ & $(0.01)$ \\
\hline \multirow[t]{2}{*}{ Acquirer CEO x Target CEO narcissism } & & & -0.541 & & 0.274 \\
\hline & & & $(0.06)$ & & $(0.20)$ \\
\hline \multirow[t]{2}{*}{ Target size } & -0.003 & -0.004 & -0.003 & -0.003 & -0.003 \\
\hline & $(0.34)$ & $(0.28)$ & $(0.32)$ & $(0.32)$ & $(0.32)$ \\
\hline \multirow[t]{2}{*}{ Target runup } & -0.063 & -0.061 & -0.062 & -0.062 & -0.063 \\
\hline & $(0.12)$ & $(0.12)$ & $(0.12)$ & (0.09) & (0.09) \\
\hline \multirow[t]{2}{*}{ Turnover $\left(x 10^{3}\right)$} & -0.288 & 0.000 & 0.000 & 0.000 & 0.000 \\
\hline & $(0.34)$ & $(0.33)$ & $(0.35)$ & $(0.33)$ & $(0.33)$ \\
\hline \multirow[t]{2}{*}{ Target NYSE/AMEX listed } & -0.007 & -0.008 & -0.007 & -0.008 & -0.008 \\
\hline & $(0.31)$ & $(0.30)$ & $(0.33)$ & $(0.32)$ & $(0.31)$ \\
\hline \multirow[t]{2}{*}{ Acquirer GIM index } & -0.003 & -0.003 & -0.003 & -0.004 & -0.003 \\
\hline & $(0.11)$ & $(0.11)$ & $(0.10)$ & $(0.06)$ & $(0.11)$ \\
\hline \multirow[t]{2}{*}{ Cash dummy } & 0.005 & 0.001 & 0.005 & 0.006 & 0.005 \\
\hline & $(0.34)$ & $(0.46)$ & $(0.34)$ & $(0.30)$ & $(0.33)$ \\
\hline \multirow[t]{2}{*}{ Multiple bidders dummy } & -0.016 & -0.015 & -0.017 & -0.017 & -0.016 \\
\hline & $(0.07)$ & $(0.10)$ & $(0.07)$ & $(0.05)$ & $(0.07)$ \\
\hline \multirow[t]{2}{*}{ Horizontal deal } & -0.027 & -0.025 & -0.026 & 0.027 & -0.028 \\
\hline & $(0.01)$ & $(0.01)$ & $(0.01)$ & $(0.01)$ & $(0.01)$ \\
\hline Number of observations & 123 & 123 & 123 & 123 & 123 \\
\hline Adjusted $\mathrm{R}^{2}$ & 0.033 & 0.013 & 0.036 & 0.038 & 0.042 \\
\hline F stat & 1.513 & 1.281 & 1.439 & 1.639 & 1.521 \\
\hline
\end{tabular}


This table reports the estimation of a probit model to analyze the determinants of deal initiation. The dependent variable is a dummy variable identifying acquirer-initiated transactions. The sample of acquisitions covers deals announced over the period 2002 to 2006 and is extracted from the Securities Data Company's (SDC) U.S. Mergers and Acquisitions Database. The extraction criteria are presented in Section II.A. Variable definitions are in Appendix B. The goodness of fit is measured by the likelihood-ratio (LR) statistic. \% Correct Prediction denotes the percentage of transactions correctly classified by the corresponding probit model. $P$-values, reported between parentheses, are bootstrapped according to the method described in Section II.C.

\begin{tabular}{|c|c|c|c|c|c|}
\hline Variable & (1) & $(2)$ & (3) & (4) & (5) \\
\hline \multirow{2}{*}{ Intercept } & -0.430 & -0.546 & -0.598 & 0.051 & 0.222 \\
\hline & $(0.00)$ & $(0.00)$ & $(0.00)$ & $(0.00)$ & $(0.00)$ \\
\hline \multirow[t]{2}{*}{ Acquirer CEO narcissism } & 3.027 & 2.915 & 3.448 & & \\
\hline & $(0.07)$ & $(0.07)$ & $(0.11)$ & & \\
\hline \multirow[t]{2}{*}{ Target CEO narcissism } & -1.176 & & & -0.924 & -4.734 \\
\hline & $(0.29)$ & & & $(0.31)$ & $(0.05)$ \\
\hline \multirow[t]{2}{*}{ Acquirer CEO x Target CEO narcissism } & & & -2.575 & & 17.624 \\
\hline & & & $(0.51)$ & & $(0.02)$ \\
\hline \multirow{2}{*}{ Acquirer leverage } & 0.718 & 0.836 & 0.783 & 0.605 & 0.735 \\
\hline & $(0.23)$ & $(0.20)$ & $(0.21)$ & $(0.22)$ & $(0.19)$ \\
\hline \multirow[t]{2}{*}{ Acquirer size } & 0.120 & 0.113 & 0.117 & 0.129 & 0.114 \\
\hline & $(0.15)$ & $(0.19)$ & $(0.18)$ & $(0.15)$ & $(0.21)$ \\
\hline \multirow[t]{2}{*}{ Target size } & -0.014 & -0.019 & -0.017 & -0.008 & -0.016 \\
\hline & $(0.80)$ & $(0.74)$ & $(0.78)$ & $(0.88)$ & $(0.79)$ \\
\hline \multirow[t]{2}{*}{ Acquirer in regulated industry } & -0.537 & -0.534 & -0.540 & -0.570 & -0.502 \\
\hline & (0.09) & $(0.08)$ & $(0.07)$ & $(0.06)$ & $(0.09)$ \\
\hline \multirow[t]{2}{*}{ Liquidity index } & -1.589 & -1.692 & -1.642 & -1.222 & -1.660 \\
\hline & $(0.34)$ & $(0.35)$ & $(0.36)$ & $(0.44)$ & $(0.35)$ \\
\hline \multirow[t]{2}{*}{ Selling Procedure Dummy } & -1.157 & -1.153 & -1.155 & -1.145 & -1.157 \\
\hline & $(0.00)$ & $(0.00)$ & $(0.00)$ & $(0.00)$ & $(0.00)$ \\
\hline Number of observations & 135 & 135 & 135 & 135 & 135 \\
\hline Likelihood ratio $\chi^{2}$ & 10.855 & 32.554 & 32.672 & 29.862 & 34.221 \\
\hline$\%$ Correctly predicted & $65.19 \%$ & $71.85 \%$ & $72.59 \%$ & $68.89 \%$ & $73.33 \%$ \\
\hline
\end{tabular}


Table V

Length of the Private Takeover Process and CEO Narcissism

This table reports the estimation of a negative binomial regression where the dependent variable is the length of the private takeover process, the number of months from the beginning of the process to the takeover announcement. The sample of acquisitions covers deals announced over the period 2002 to 2006 and is extracted from the Securities Data Company's (SDC) U.S. Mergers and Acquisitions Database. The extraction criteria are presented in Section II.A. Variable definitions are in Appendix B. P-values, reported between parentheses, are bootstrapped according to the method described in Section II.A.

\begin{tabular}{|c|c|c|c|c|c|}
\hline Variable & (1) & $(2)$ & (3) & (4) & (5) \\
\hline \multirow[t]{2}{*}{ Intercept } & 3.230 & 3.262 & 3.259 & 2.619 & 2.879 \\
\hline & $(0.01)$ & $(0.01)$ & $(0.01)$ & $(0.20)$ & $(0.00)$ \\
\hline \multirow[t]{2}{*}{ Acquirer CEO narcissism } & -1.972 & -1.944 & -1.589 & & \\
\hline & $(0.02)$ & $(0.01)$ & $(0.11)$ & & \\
\hline \multirow[t]{2}{*}{ Target CEO narcissism } & 0.178 & & & -0.083 & 2.653 \\
\hline & (0.69) & & & $(0.85)$ & $(0.02)$ \\
\hline \multirow[t]{2}{*}{ Acquirer CEO x Target CEO narcissism } & & & -1.576 & & -11.905 \\
\hline & & & $(0.47)$ & & $(0.00)$ \\
\hline \multirow[t]{2}{*}{ Concentration target sales } & -0.143 & -0.138 & -0.123 & -0.098 & -0.108 \\
\hline & $(0.33)$ & $(0.33)$ & $(0.39)$ & $(0.55)$ & $(0.40)$ \\
\hline \multirow[t]{2}{*}{ Target initiated dummy } & 0.194 & 0.196 & 0.198 & 0.243 & 0.175 \\
\hline & $(0.08)$ & $(0.08)$ & $(0.08)$ & $(0.04)$ & $(0.09)$ \\
\hline \multirow[t]{2}{*}{ Acquirer GIM index } & -0.076 & -0.077 & -0.078 & -0.058 & -0.082 \\
\hline & $(0.02)$ & $(0.02)$ & $(0.02)$ & $(0.04)$ & $(0.00)$ \\
\hline \multirow[t]{2}{*}{ Acquirer in regulated industry } & -0.155 & -0.155 & -0.160 & -0.165 & -0.179 \\
\hline & (0.19) & $(0.21)$ & $(0.20)$ & $(0.31)$ & (0.10) \\
\hline \multirow[t]{2}{*}{ Acquirer M\&A experience } & -0.129 & -0.128 & -0.129 & -0.117 & -0.150 \\
\hline & $(0.02)$ & $(0.01)$ & $(0.02)$ & $(0.06)$ & $(0.01)$ \\
\hline \multirow[t]{2}{*}{ Acquirer leverage } & -0.053 & -0.080 & -0.126 & -0.007 & -0.024 \\
\hline & $(0.78)$ & $(0.69)$ & $(0.59)$ & $(0.92)$ & $(0.86)$ \\
\hline \multirow[t]{2}{*}{ Relative size } & -0.198 & -0.194 & -0.187 & -0.145 & -0.219 \\
\hline & $(0.05)$ & $(0.05)$ & $(0.05)$ & $(0.07)$ & $(0.03)$ \\
\hline \multirow[t]{2}{*}{ Gamma } & 0.673 & 0.675 & 0.673 & 0.761 & 0.621 \\
\hline & $(0.00)$ & $(0.00)$ & $(0.00)$ & $(0.00)$ & $(0.00)$ \\
\hline Number of observations & 122 & 122 & 122 & 122 & 122 \\
\hline log-likelihood & 963.06 & 963.03 & 963.15 & 960.04 & 964.98 \\
\hline
\end{tabular}


Table VI

Ex-ante Probability of Deal Completion and CEO Narcissism

This table reports ordinary least square regression where the dependent variable is the ex-ante probability of deal completion. The sample of acquisitions covers deals announced over the period 2002 to 2006 and is extracted from the Securities Data Company's (SDC) U.S. Mergers and Acquisitions Database. The extraction criteria are presented in Section II.A. Variable definitions are in Appendix B. P-values, reported between parentheses, are estimated using White heteroskedastic-consistent standard errors and are bootstrapped according to the method described in Section II.C.

\begin{tabular}{|c|c|c|c|c|c|}
\hline Variable & (1) & $(2)$ & (3) & (4) & (5) \\
\hline Intercept & $\begin{array}{l}1.286 \\
(0.00)\end{array}$ & $\begin{array}{l}1.216 \\
(0.00)\end{array}$ & $\begin{array}{l}1.200 \\
(0.00)\end{array}$ & $\begin{array}{l}1.096 \\
(0.02)\end{array}$ & $\begin{array}{l}1.114 \\
(0.01)\end{array}$ \\
\hline Acquirer CEO narcissism & $\begin{array}{r}-0.666 \\
(0.02)\end{array}$ & $\begin{array}{r}-0.705 \\
(0.01)\end{array}$ & $\begin{array}{r}-0.482 \\
(0.15)\end{array}$ & & \\
\hline Target CEO narcissism & $\begin{array}{r}-0.516 \\
(0.04)\end{array}$ & & & $\begin{array}{r}-0.557 \\
(0.02)\end{array}$ & $\begin{array}{r}-0.270 \\
(0.30)\end{array}$ \\
\hline Acquirer CEO x Target CEO narcissism & & & $\begin{array}{r}-1.046 \\
(0.16)\end{array}$ & & $\begin{array}{r}-1.325 \\
(0.21)\end{array}$ \\
\hline Target size & $\begin{array}{r}-0.043 \\
(0.03)\end{array}$ & $\begin{array}{r}-0.047 \\
(0.01)\end{array}$ & $\begin{array}{r}-0.045 \\
(0.01)\end{array}$ & $\begin{array}{r}-0.043 \\
(0.02)\end{array}$ & $\begin{array}{r}-0.042 \\
(0.02)\end{array}$ \\
\hline Cash dummy & $\begin{array}{l}0.061 \\
(0.20)\end{array}$ & $\begin{array}{c}0.047 \\
(0.28)\end{array}$ & $\begin{array}{r}0.053 \\
(0.23)\end{array}$ & $\begin{array}{r}0.051 \\
(0.23)\end{array}$ & $\begin{array}{l}0.056 \\
(0.21)\end{array}$ \\
\hline Horizontal deal & $\begin{array}{r}-0.075 \\
(0.07)\end{array}$ & $\begin{array}{r}-0.070 \\
(0.09)\end{array}$ & $\begin{array}{r}-0.076 \\
(0.09)\end{array}$ & $\begin{array}{r}-0.068 \\
(0.10)\end{array}$ & $\begin{array}{r}-0.068 \\
(0.11)\end{array}$ \\
\hline Acquirer GIM index & $\begin{array}{l}0.006 \\
(0.34)\end{array}$ & $\begin{array}{l}0.007 \\
(0.31)\end{array}$ & $\begin{array}{l}0.006 \\
(0.32)\end{array}$ & $\begin{array}{l}0.011 \\
(0.14)\end{array}$ & $\begin{array}{l}0.009 \\
(0.20)\end{array}$ \\
\hline Number of observations & 112 & 112 & 112 & 112 & 112 \\
\hline Adjusted $\mathrm{R}^{2}$ & 0.088 & 0.070 & 0.073 & 0.064 & 0.068 \\
\hline F stat & 2.794 & 2.850 & 2.430 & 2.696 & 2.319 \\
\hline
\end{tabular}

